\title{
Breakfast Skipper and Breakfast Eater: Which Is Better
}

\author{
Fendy Susanto \\ Health Food Innovation Management Program Maastricht University, Campus Venlo, the Netherlands
}

Email address:

fendysusanto62@gmail.com

\section{To cite this article:}

Fendy Susanto. Breakfast Skipper and Breakfast Eater: Which Is Better. International Journal of Nutrition and Food Sciences. Vol. 4, No. 5, 2015, pp. 565-573. doi: 10.11648/j.ijnfs.20150405.18

\begin{abstract}
Regular breakfast consumption has been acknowledged as an opportunity to meet nutrition recommendation and more favorable weight status. However, in Indonesia, breakfast skipping prevalence for school aged children is commonly found, as it ranged from $16.9 \%$ to $59 \%$, with no exemption for Jakarta. The aims of present study were to compare nutrient intakes and weight status between breakfast eaters and non-breakfast eaters within different demographic subgroups, and additionally, to propose healthy breakfast recommendation based on condition of local population. $2^{\text {nd }}$ Indonesian National Basic Health Research Survey (RISKESDAS) in a cross-sectional setting were analyzed using 24-hr dietary recall. The main sample consisted of children age 6- to 12- year old randomly selected in Jakarta area $(n=945)$. Overall, breakfast consumers had higher daily energy, carbohydrate, protein, and micronutrients intake although for some micronutrients, these were not statistically significant. There is no significant difference between the two groups in terms of weight status. Skipping breakfast was more prevalent in girls $(6.43 \%$ versus $3.64 \%)$, older children group (6.5\% for $10-12$ year group; $4.4 \%$ for $7-9$ year group, and $2.2 \%$ for 6 year group), and low SES which was about $4.3 \%$, respectively. About $39 \%$ of school aged children living in Jakarta consumed breakfast less than $15 \%$ Indonesian DRI, respectively. Furthermore, this study supported the current breakfast recommendation which was $15-30 \%$ of energy from Indonesian DRI with some additional encouragement. To encourage breakfast consumption among the population, some recommendation were also given within the study.
\end{abstract}

Keywords: Breakfast Skipper, Breakfast Eater, Nutrient Intake, Children, Jakarta

\section{Introduction}

There has been a marked increase in the number of children and adolescents who routinely skip their breakfast $(1,2)$. In United States, the rate of skipping breakfast in children and adolescents generally ranges from $10 \%$ to $30 \%$ depending on age group, gender, race, ethnicity, and how breakfast skipping is defined (3). Not only in United States, a decline in regular breakfast consumption has also been reported in Asia (4-6), Canada (7), Australia (8), and several countries in Europe (9-14). In Hong Kong, approximately $10 \%$ of school aged children and adolescents were reported to skip their breakfast at least 4 times a week (5), while in Malaysia, it has been found that breakfast is the most frequently missed meal (4). Similar condition was also found in Taiwan, approximately $23.6 \%$ participants in their study reported that they ate breakfast irregularly on the schooldays (6). In Indonesia, nearly half of the children population $(44.6 \%)$ still has breakfast with low nutritional quality (15). Numerous unpublished studies results in Indonesia conducted from 2002 to 2011 also showed that breakfast skipping prevalence for school children ranged from $16.9 \%$ to $59 \%$ (15). No exemption for Jakarta, breakfast skipping is also happened among the school age children. Soedibyo and Gunawan (2009) in small scale study involving 58 subjects in one hospital at Jakarta reported that approximately $22.4 \%$ routinely had skipped their breakfast.

It also has been found that girls are more likely to skip breakfast than boys $(2,3,16,17)$ although it may be different in a non-Western population (18). Study in Hong Kong reported that girls were less likely to skip breakfast compared with boys, this result suggested that there may be an impact of local cultures on the breakfast skipping phenomenon (18). Breakfast skipping also increases as children age to adolescence $(3,19,20)$. Moreover, breakfast skipping has been generally associated with the lower socioeconomic status (SES) $(19,21,22)$. In Jakarta, to the best of author's knowledge, there have been no previous studies examining the relationship of different demographics situation such as gender, age, and SES to breakfast skipping prevalence in children, hence suggesting further investigation.

Numerous studies have shown the nutritional benefits of 
breakfast (3). For instance, compared with children who consumed breakfast regularly, those who skipped breakfast were likely to have an inadequate diet with poorer nutrient intakes (23). Breakfast consumers tend to have higher daily energy intake in comparison with the breakfast skippers (24, $13,17)$, while their weight status is still lower (25).

Some studies have also reported that compare to breakfast consumers, breakfast skippers have lower intakes of carbohydrate, protein, and total fat, yet there is no differences in other studies (3). A set of studies were also reported that breakfast consumption is frequently associated with higher intakes of some nutrients, particularly vitamin A, vitamin $\mathrm{C}$, riboflavin (vitamin $\mathrm{B}_{2}$ ), calcium, zinc, and iron $(3,24,26)$. This may boost the likelihood of meeting daily requirement recommendation as a percentage of DRIs. Fiber intake was also enhanced by regularly consuming breakfast which is currently lacking in children dietary diets $(3,14,17)$. As an essential micronutrient for bone development for children growth, calcium intake was also improved by regular breakfast consumption (3). Breakfast skippers tend to not make up for missed energy or nutrient intake through next daily meals thus, highlighting the beneficial effect of having breakfast to meet nutrient intake recommendation (27).

To the best of our knowledge, there are only limited published studies investigating the impact of skipping breakfast focused in Jakarta children population, suggesting that further research is still needed to elucidate the importance of breakfast consumption in this population. Therefore, in this study, we aimed to assess the impact of breakfast skipping to daily nutrient intake among Jakarta primary school children.

Despite the facts that there have been extensive set of studies supporting the relationship between importance of having breakfast with nutritional adequacy, inconsistencies were still found in terms of weight status and obesity risk (3, $24,28,29)$. For example, the 5 year-prospective project EAT (Eating Among Teens) study which examined the association between breakfast frequency and body weight change in 2,216 adolescents revealed that there was an inverse associations between breakfast frequency and BMI which were strongly independent of confounding and another dietary factors (30). Furthermore, another 3-year Growing Up Today Study (GUTS) which examined the relationship between skipping breakfast and weight change in more than 14,000 adolescent reported that normal weight children who skipped breakfast tended to have greater BMI increases compared to breakfast eaters, yet this finding was not statistically significant (31). Recent review published also reported that breakfast skippers have a significantly higher BMI compared with youth who consumed breakfast more frequent (3). Another supporting study from Malaysia found out that infrequent breakfast consumption is associated with higher body adiposity and abdominal obesity as well as higher BMI level in comparison with its counterpart (32) while in Taiwan, it is indicated that adolescents with regular breakfast consumption had a lower risk of being overweight. In the same study, it was also reported that the odds of being overweight for irregular breakfast eating is $51 \%$ higher than having breakfast regularly even after controlling demographical variables (6).

In contrast, Berkey and colleagues reported that for overweight adolescent at baseline who skipped breakfast resulted in BMI losses over time (31) suggesting that breakfast omission might results in weight loss (27). Another non-supporting studies from Australia, Portugal, and Saudi Arabia have reported that there was no association between infrequent breakfast consumption with obesity risk or body weight and composition $(24,28,29)$. Such inconsistencies between these studies again may be explained as there are differences in definition used for breakfast skipping and in the selection of confounding variables including parental education, physical activity, or socio-economic status. This also suggests that breakfast might not affect BMI directly but rather through its association with other lifestyles and demographic factors (20).

The exact mechanism by which breakfast consumption may help to maintain healthy weight status is still not clear (27). Some suggest that breakfast consumption may contribute to greater satiety response through variety of metabolic effects related to glycemic and insulin response, which should have resulted in lower daily energy intake (33). Conversely, research have shown that daily energy intake of breakfast consumers were significantly higher than breakfast skippers $(24,13,17,23)$. Breakfast consumption has also been associated with higher physical activity levels in children and adolescents (27) which may explained the healthy weight maintenance. In general, breakfast consumption has been linked to better overall diet quality, which may translate into healthier lifestyle and boost the likelihood of maintaining healthy weight.

As the bottom line, breakfast consumption is essential since skipping this important meal has become increasingly common in parallel with the escalation of childhood obesity (34), with no exemption for Jakarta (35). Taken as a whole, these data are inconclusive, and more research is needed to investigate the influence of breakfast consumption to weight status mainly in Jakarta, since there are also very limited studies investigating this relationship among school aged children in the area.

Furthermore, there is no current single consensus among researchers and consumers on definition for breakfast (27). Several definitions have been made based on different aspects such as type of food, amount of food, or the time of day it was consumed (27). More broadly, there are also other recommendations on how healthy breakfast should be defined. For instance, in one meta-analysis study, it is reported that the most widely held definition agreed is that breakfast needs to contain at least $10 \%$ of RDA for energy and food from at least 2 major groups, based on the definition from USDA (United States Department of Agriculture). For school breakfast programs, it has even stricter definition which includes food from 2-3 groups and total nutrients equal or more than $25 \%$ of RDA for total calories, protein, certain vitamins, and minerals (36). Timlin and Pereira (2007) stated that as a working definition, breakfast is defined as "the first meal of the day, eaten before or at the start of daily activities (e.g. errands, 
travel, work, school), within 2 hours of waking, typically no later than 10:00 in the morning, and of an energy level between 20 and $35 \%$ of total daily energy needs" (33).

Another recommendation comes from Netherlands Nutrition Centre (NNC), stated that healthy breakfast should provide about $15 \%$ of the age-specific daily recommended energy intake, a maximum of $9 \%$ of energy of saturated fat, and a minimum of $1.4 \mathrm{~g}$ of fibers per $100 \mathrm{kcal}$ (37). Williams (2007) in Australia suggested that breakfast should be low in fat (26 to $30 \%$ of energy come from fat), high in carbohydrate (providing $55-58 \%$ of energy), a significant source of fiber, and rich in micronutrients (24). In Indonesia, recent recommendation stated that breakfast should contain 15 to $30 \%$ of daily energy intake from Indonesian DRI (38). Nonetheless, when proposing breakfast recommendation, one should also consider the influence of traditional dietary habits within the given country. Most of the existing scientific studies currently used as basis for recommendation come from North-American and Commonwealth countries (39), whose dietary uses and lifestyles are typically different when compared to other regional or countries. In Indonesia and most of Asian countries, rice consumption is prevalent while Ready-to-Eat (RTE) breakfast cereals are more familiar type of breakfast consumed in most of European and Western countries. An example, in Japan, rice is acknowledged as the main breakfast type to be consumed for children (40). The influence of culture also occurred in Indonesia. Soedibyo and Gunawan in their study (41), showed that rice and side dishes were the prevalent type of breakfast consumed for children in Jakarta which accounted approximately $30 \%$ compared to other types of food.

As a summary, lack of universal breakfast recommendation which maybe resulted from differences in traditional dietary habit has led this research to propose healthy breakfast recommendation based on specific population data, such as in Jakarta's school age children population. Moreover, although healthy breakfast recommendation already existed for Indonesian school age children, further research is still needed based on local population assessment. At the end, this finding will support national health promotion activities and establishment of the official recommendation breakfast guidelines.

In conclusion, the aim of present study was to compare the nutrient intakes and weight status between breakfast eaters and non-breakfast eaters within different demographic subgroups and third, to propose healthy breakfast recommendations based on local population condition.

\section{Method}

The data used within this study is a secondary data obtained from $2^{\text {nd }}$ Indonesian National Basic Health Research Survey (RISKESDAS Riset Kesehatan Dasar) which was conducted from May to August 2010. School age children age 6- to 12year old randomly selected in Jakarta area was the main study population. Subject identity data were collected using family assessment questionnaire and interview method, this includes 24-hr dietary recall questionnaires. SES categorization was assessed by Indonesian Central Statistics Bureau using quintile with the $1^{\text {st }}$ and $2^{\text {nd }}$ quintile as low SES, $3^{\text {rd }}$ quintile as medium SES, and $4^{\text {th }}$ and $5^{\text {th }}$ quintile as high SES.

Nutrisurvey for Windows 2005 software was used to analyze micronutrients content (University of Indonesia, SEAMEO-TROPMED). If data for particular food does not exist in the software, then DKBM database (Indonesian Food Consumption Database) published by Indonesian Ministry of Food and Agriculture was used. For Indonesian Dietary Intake Reference, AKG 2004 (Angka Kecukupan Gizi) was used as the standard for each age category. For carbohydrate, fiber, and fat, DRI (Dietary Reference Intake) from Institute of Medicine (2005) were used as a standard. Body Mass Index (BMI) was calculated as weight $/$ height $^{2}\left(\mathrm{~kg} / \mathrm{m}^{2}\right)$ whilst BMI $z$-score was calculated for further analysis using WHO 2007 formula.

\subsection{Breakfast Definition and Design of Breakfast Categories}

For breakfast status analysis in this study, breakfast eaters are operationalized as subjects who consumed any types of food or milk in the morning. Subjects that took no foods at all or consumed only water, tea, or other liquid (excluding milk) were considered as breakfast skippers or non-breakfast eaters.

However, in order to propose healthy breakfast recommendation, breakfast categories was defined based on percentage energy content of the age specific Indonesian daily recommended energy intake (ranging from $5 \%$ to $35 \%$ of age specific Indonesian DRI) (38).

Table 1. Means (SD) and percentages of subject characteristics.

\begin{tabular}{ll}
\hline & $n$ sample (percentages or mean \pm SD) \\
\hline Gender & $494(52.3 \%)$ \\
Boys & $451(47.7 \%)$ \\
Girls & \\
Socioeconomic status (SES) & $610(64.6 \%)$ \\
Low & $198(21.0 \%)$ \\
Medium & $137(14.5 \%)$ \\
High & $9.00 \pm 1.972$ \\
Age (years) & $134(14.2 \%)$ \\
6 years old & $409(43.3 \%)$ \\
$7-9$ years old & $402(42.5 \%)$ \\
10-12 years old & $29.99 \pm 10.00$ \\
Weight (kg) & $129.5 \pm 14.81$ \\
Height (cm) & $17.63 \pm 4.055$ \\
BMI for age (WHO 2007) & $72(7.6 \%)$ \\
Underweight & $565(59.8 \%)$ \\
Normal & $308(32.6 \%)$ \\
Overweight/Obese & $898(95.0 \%)$ \\
Breakfast Status & $47(5 \%)$ \\
Breakfast eaters & \\
Breakfast skippers & \\
\hline
\end{tabular}

\subsection{Statistical Analysis}

All the statistical analyses were conducted using SPSS version 17.0 for Windows. Analysis of covariance (ANCOVA) was conducted to analyze whether there was differences in nutrient intakes and BMI $z$-score according to breakfast status (breakfast eaters versus breakfast skippers) adjusted for SES, age, and gender. These variables were chosen as covariates 
because they could confound the relationship between breakfast status and BMI z-score or nutrient intake (56). Post-hoc analysis was performed with Bonferroni method. Additionally, ANCOVA analysis was performed to analyze different groups of breakfast classes (5\% to $35 \%$ energy content in breakfast based on age specific Indonesian DRI), adjusted for SES, gender, and age. $P$-value of $<0.05$ was considered to be statistically significant.

\section{Results}

Total 945 children were involved in the study and their characteristics were described in Tabel 1. Boys were involved in higher number than girls ( $52 \%$ versus $48 \%$ ) with a mean age of 9 years. More than half $(64.6 \%)$ of the children were coming from high socio-economic status family in Jakarta $\left(4^{\text {th }}\right.$ and $5^{\text {th }}$ quintile based on Indonesian Central Statistics Bureau). Among the population, breakfast skipper is about 5\%.

\subsection{Comparison of Breakfast Consumers and Breakfast Skippers}

Those who had breakfast significantly consumed more daily energy ( $p<0.001)$, carbohydrate $(p<0.01)$, protein, fat, vitamin $\mathrm{B}_{2}$, calcium, and zinc $(p<0.05)$ but no significant differences were found in fiber intake and other micronutrients, although still considered higher intake. Breakfast contributed significantly to meet daily protein intake requirement (51 g versus $41 \mathrm{~g}$ ). However, other nutrients still did not meet standard requirements as shown in Table 2. Data on BMI $z$-score showed that there was no significance difference between two groups.

Table 2. Contribution of Breakfast Status to Total Nutrient Intake and Weight Status within Jakarta children age 6-12 years old $†$.

\begin{tabular}{|c|c|c|c|c|}
\hline Breakfast Status & Breakfast consumers & Breakfast skippers & Recommended Intake $\$$ & Pvalue \\
\hline Nutrient & $n=898$ & $n=47$ & & \\
\hline Energy (kcal) & $1446(21.1)$ & $1103(92.5)$ & $1800-2050$ & $p<0.001$ \\
\hline Carbohydrate (g) & $198(3.2)$ & $149(13.9)$ & 130 & $p<0.01$ \\
\hline Protein $(\mathrm{g})$ & $51(0.9)$ & $41(3.9)$ & $45-50$ & $p<0.05$ \\
\hline Fat $(g)^{\S}$ & $48.9(1.0)$ & $36.8(4.6)$ & $25-35$ & $p<0.05$ \\
\hline Fiber $(\mathrm{g})$ & $5.77(0.1)$ & $4.66(0.6)$ & $25-31$ & ns \\
\hline Vitamin A (RE) & $546.6(31.1)$ & $406.4(136.5)$ & $500-600$ & ns \\
\hline Vitamin $\mathrm{B}_{2}(\mathrm{mg})$ & $0.8(0.02)$ & $0.5(0.09)$ & $0.9-1.0$ & $p<0.05$ \\
\hline Vitamin $B_{6}(\mathrm{mg})$ & $0.74(0.02)$ & $0.86(0.08)$ & $1-1.3$ & ns \\
\hline Vitamin C (mg) & $26.64(1.8)$ & $33.77(7.8)$ & $45-50$ & ns \\
\hline Calcium (mg) & $461.9(21.7)$ & $216.4(95.4)$ & $600-1000$ & $p<0.05$ \\
\hline Iron (mg) & $8.05(0.9)$ & $4.44(4.4)$ & $10-13$ & ns \\
\hline Zinc (mg) & $5.97(0.1)$ & $4.5(0.5)$ & $11.2-14$ & $p<0.01$ \\
\hline BMI $z$-score & $0.32(0.1)$ & $0.34(0.3)$ & - & ns \\
\hline
\end{tabular}

'All values are presented as means (SE), mean values was adjusted with age, SES, and gender

\$ Recommended intake is based on Indonesian DRI (AKG 2004) and Dietary Reference Intakes 2005 by Institute of Medicine of The National Academies for carbohydrate and fiber

${ }^{\S}$ For fat, the Acceptable Macronutrient Distribution Ranges from Institute of Medicine is used.

${ }^{*} p<0.05$ is considered as statistically significant

Table 3. Comparison of the daily nutrient intakes and BMI z-score of breakfast eaters and skippers across different age groups in within Jakarta children .

\begin{tabular}{|c|c|c|c|c|c|c|c|c|c|}
\hline & \multicolumn{3}{|c|}{6 years old } & \multicolumn{3}{|c|}{ 7-9 years old } & \multicolumn{3}{|c|}{ 10-12 years old } \\
\hline & $\begin{array}{l}\text { Eaters } \\
(n=131)\end{array}$ & $\begin{array}{l}\text { Skippers } \\
(n=3)\end{array}$ & $P$-value & $\begin{array}{l}\text { Eaters } \\
(n=391)\end{array}$ & $\begin{array}{l}\text { Skippers } \\
(\mathrm{n}=18)\end{array}$ & P-value & $\begin{array}{l}\text { Eaters } \\
(n=376)\end{array}$ & $\begin{array}{l}\text { Skippers } \\
(\mathrm{n}=\mathbf{2 6})\end{array}$ & P-value \\
\hline Energy (kcal) & 1470.2 & 836.4 & $p<0.05$ & 1436.8 & 1098.5 & $p<0.05$ & 1446.5 & 1143.2 & $p<0.05$ \\
\hline Protein (g) & 53 & 37.9 & ns & 51.1 & 44.2 & ns & 50.3 & 39.1 & $p<0.05$ \\
\hline Fat $(\mathrm{g})^{\S}$ & 50.3 & 34.9 & ns & 48.5 & 34.8 & $\mathrm{~ns}$ & 48.9 & 38.6 & $\mathrm{~ns}$ \\
\hline Fiber $(\mathrm{g})$ & 4.9 & 6.3 & ns & 5.8 & 3.4 & ns & 5.9 & 5.5 & ns \\
\hline Vitamin $B_{1}(\mathrm{mg})$ & 0.5 & 0.3 & ns & 0.4 & 0.3 & $p<0.05$ & 0.4 & 0.3 & ns \\
\hline Vitamin $B_{2}(m g)$ & 0.9 & 0.6 & ns & 0.8 & 0.6 & ns & 0.7 & 0.4 & $p<0.05$ \\
\hline Vitamin $\mathrm{B}_{6}(\mathrm{mg})$ & 0.7 & 0.5 & ns & 0.7 & 1.3 & $p<0.01$ & 0.7 & 0.6 & $\mathrm{~ns}$ \\
\hline Vitamin C (mg) & 34.4 & 163.4 & $p<0.01$ & 25.9 & 30.3 & ns & 24.9 & 19.5 & ns \\
\hline Calcium (mg) & 657.3 & 217.9 & ns & 480.2 & 183.4 & ns & 376.4 & 215.8 & ns \\
\hline Iron (mg) & 8.1 & 3.4 & ns & 9.5 & 2.9 & ns & 6.6 & 4.6 & ns \\
\hline Zinc (mg) & 6.2 & 4.1 & ns & 5.9 & 4.8 & ns & 5.9 & 4.4 & $p<0.05$ \\
\hline BMI z-score & 0.5 & 1.7 & ns & 0.4 & -0.023 & ns & 0.2 & 0.5 & ns \\
\hline
\end{tabular}

${ }^{\dagger}$ All values are presented as means (SE), mean values was adjusted with age, SES, and gender

$\$$ Recommended intake is based on Indonesian DRI (AKG 2004) and Dietary Reference Intakes 2005 by Institute of Medicine of The National Academies for carbohydrate and fiber

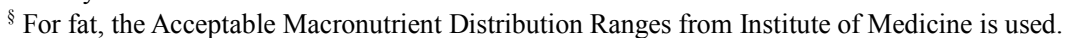

${ }^{*} p<0.05$ is considered as statistically significant 
Table 4. Comparison of the daily nutrient intakes and BMI z-score of breakfast eaters and skippers across different gender in within Jakarta children

\begin{tabular}{|c|c|c|c|c|c|c|}
\hline & \multicolumn{3}{|l|}{ Boys } & \multicolumn{3}{|l|}{ Girls } \\
\hline & Eaters $(n=476)$ & Skippers $(n=18)$ & $P$-value & Eaters $(n=422)$ & Skippers $(n=29)$ & $P$-value \\
\hline Energy (kcal) & 1490.9 & 1070.05 & $p<0.01$ & 1396.8 & 1098. & $p<0.01$ \\
\hline Carbohydrate (g) & 203.2 & 145.76 & $p<0.05$ & 192.6 & 148.3 & $p<0.05$ \\
\hline Fat $(g)^{\S}$ & 50.8 & 37.45 & ns & 46.9 & 35.5 & $p<0.05$ \\
\hline Fiber $(\mathrm{g})$ & 5.9 & 5.39 & ns & 5.5 & 4.1 & ns \\
\hline Vitamin A (RE) & 583.4 & 181.12 & $\mathrm{~ns}$ & 505.6 & 541.1 & $\mathrm{~ns}$ \\
\hline Vitamin $B_{2}(m g)$ & 0.8 & 0.485 & $p<0.05$ & 0.8 & 0.5 & $p<0.05$ \\
\hline Vitamin $B_{6}(\mathrm{mg})$ & 0.8 & 0.545 & $p<0.05$ & 0.7 & 1.1 & $p<0.05$ \\
\hline Vitamin C (mg) & 27.6 & 44.32 & ns & 25.6 & 26.2 & ns \\
\hline Calcium (mg) & 473.3 & 152.74 & $p<0.05$ & 449.8 & 245.7 & ns \\
\hline Iron (mg) & 7.3 & 3.72 & $p<0.05$ & 8.9 & 5.0 & ns \\
\hline Zinc (mg) & 6.2 & 3.855 & $p<0.01$ & 5.7 & 4.8 & ns \\
\hline BMI $z$-score & 0.4 & 0.679 & ns & 0.3 & 0.1 & ns \\
\hline
\end{tabular}

${ }^{\dagger}$ All values are presented as means (SE), mean values was adjusted with age, SES, and gender

+ Recommended intake is based on Indonesian DRI (AKG 2004) and Dietary Reference Intakes 2005 by Institute of Medicine of The National Academies for carbohydrate and fiber

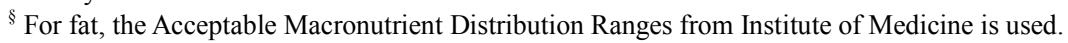

${ }^{*} p<0.05$ is considered as statistically significant

Table 5. Comparison of the daily nutrient intakes and BMI z-score of breakfast eaters and skippers across different SES group in within Jakarta children $†$

\begin{tabular}{|c|c|c|c|c|c|c|c|c|c|}
\hline & \multicolumn{3}{|l|}{ Low SES } & \multicolumn{3}{|c|}{ Medium SES } & \multicolumn{3}{|l|}{ High SES } \\
\hline & $\begin{array}{l}\text { Eaters } \\
(n=131)\end{array}$ & $\begin{array}{l}\text { Skippers } \\
(\mathrm{n}=6)\end{array}$ & P-value & $\begin{array}{l}\text { Eaters } \\
(n=186)\end{array}$ & $\begin{array}{l}\text { Skippers } \\
(\mathrm{n}=12)\end{array}$ & P-value & $\begin{array}{l}\text { Eaters } \\
(n=581)\end{array}$ & $\begin{array}{l}\text { Skippers } \\
(n=29)\end{array}$ & $P$-value \\
\hline Energy (kcal) & 1244.1 & 946.3 & $\mathrm{~ns}$ & 1434.9 & 1109.57 & $\mathrm{~ns}$ & 1496.1 & 1110.5 & $p<0.01$ \\
\hline Carbohydrate (g) & 172.1 & 138.3 & ns & 198.6 & 171.32 & ns & 203.9 & 140.6 & $p<0.01$ \\
\hline Protein $(\mathrm{g})$ & 39.6 & 34.2 & ns & 48.2 & 28.85 & $p<0.01$ & 54.6 & 46.9 & ns \\
\hline Fat $(\mathrm{g})^{\S}$ & 43.6 & 27.9 & ns & 48.8 & 33.45 & ns & 50.3 & 38.6 & $p<0.05$ \\
\hline Fiber $(\mathrm{g})$ & 5.1 & 6.9 & ns & 5.6 & 4.833 & ns & 5.9 & 4.1 & $p<0.05$ \\
\hline Vitamin $B_{1}(\mathrm{mg})$ & 0.3 & 0.3 & ns & 0.4 & 0.320 & ns & 0.5 & 0.3 & $p<0.05$ \\
\hline Vitamin $B_{2}(\mathrm{mg})$ & 0.6 & 0.3 & ns & 0.7 & 0.486 & ns & 0.9 & 0.6 & $p<0.05$ \\
\hline Vitamin $B_{6}(\mathrm{mg})$ & 0.6 & 0.5 & ns & 0.7 & 1.608 & $p<0.01$ & 0.9 & 0.6 & $p<0.05$ \\
\hline Vitamin C (mg) & 13.8 & 99.2 & $p<0.001$ & 19.6 & 60.75 & $p<0.01$ & 31.9 & 7.9 & $p<0.05$ \\
\hline Calcium (mg) & 273.4 & 81.9 & ns & 415.2 & 281.65 & ns & 519.7 & 210.8 & $p<0.05$ \\
\hline Iron (mg) & 5.4 & 2.7 & ns & 6.3 & 4.362 & ns & 9.2 & 4.7 & ns \\
\hline Zinc (mg) & 4.6 & 3.1 & ns & 5.8 & 3.814 & ns & 6.3 & 5.0 & ns \\
\hline
\end{tabular}

${ }^{\dagger}$ All values are presented as means (SE), mean values was adjusted with age, SES, and gender

\$ Recommended intake is based on Indonesian DRI (AKG 2004) and Dietary Reference Intakes 2005 by Institute of Medicine of The National Academies for carbohydrate and fiber

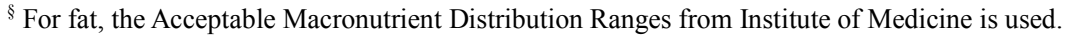

${ }^{*} p<0.05$ is considered as statistically significant

Within different demographic subgroups (age, gender, and socioeconomic status) as shown in Table 3-5, the findings showed that breakfast eaters significantly consumed higher total daily energy intake compared with non-breakfast eaters. Correspondingly, breakfast eaters also tended to have statistically higher daily intake of carbohydrates. For fat and protein, breakfast eaters also consumed higher daily amount in comparison with its counterpart, although in this study, it was not statistically significant.

Fiber intake was not statistically significant among all different subgroups with exception for high SES subgroup. Overall, those who ate breakfast in the survey day reported to have richer daily consumption of micronutrients such as vitamin $B_{1}$, vitamin $B_{2}$, vitamin $C$, and zinc although the differences were not always statistically significant mainly in younger and lower SES group.

In comparison with boys, girls was reported to skip their breakfast in higher proportion (6.4\% versus $3.6 \%)$ while in older children group, not eating breakfast was also more prevalent, e.g. $6.5 \%$ for $10-12$ year group; $4.4 \%$ for $7-9$ year group, and $2.2 \%$ for 6 year group. Based on SES, the low SES group reported to have the highest prevalence of skipping breakfast, which was about $4.3 \%$.

\subsection{Subject Characteristics Based on Energy Intake During Breakfast}

As shown in Table 6, approximately $39 \%$ of school aged children living in Jakarta consumed breakfast less than $15 \%$ of Indonesian DRI. Although for several micronutrients and daily energy intake were still not adequate, the closest mean 
energy and micronutrients intake with recommendation were in $30-35 \%$ DRI group. However, there was no statistically significant difference between $25-30 \%$ DRI with $30-35 \%$ DRI group in terms of daily energy intake. Furthermore, in terms of micronutrient intake, no significant difference also found between $15-20 \%$ DRI with the 30-35\% DRI group.

Table 6. Effect of Different Breakfast Energy Content based on Indonesian DRI to Total Daily Nutrient Intake and BMI z-score†.

\begin{tabular}{|c|c|c|c|c|c|c|c|c|}
\hline \multirow{2}{*}{ Nutrient } & $0-5 \%$ & $5-15 \%$ & $15-20 \%$ & $20-25 \%$ & $25-30 \%$ & $30-35 \%$ & DRI: & Pvalue \\
\hline & $n=77$ & $n=292$ & $n=153$ & $n=121$ & $n=57$ & $n=33$ & & \\
\hline Energy (kcal) & $984.2^{\mathrm{a}}(56.4)$ & $1052.7^{\mathrm{a}}(28.9)$ & $1328.5^{\mathrm{b}}(39.8)$ & $1402.2^{\text {bc }}(44.8)$ & $1622.9^{\mathrm{cd}}(65.3)$ & $1706.1^{\mathrm{d}}(85.7)$ & $1800-2050$ & $p<0.001$ \\
\hline $\mathrm{CHO}(\mathrm{g})$ & $132.3^{\mathrm{a}}(9.1)$ & $145.7^{\mathrm{a}}(4.6)$ & $179.6^{\text {bd }}(6.4)$ & $195.7^{\mathrm{bc}}(7.2)$ & $224.7^{\mathrm{c}}(10.5)$ & $225.2^{\mathrm{cd}}(13.7)$ & 130 & $p<0.001$ \\
\hline Protein $(\mathrm{g})$ & $36.6^{\mathrm{a}}(2.7)$ & $37.4^{\mathrm{a}}(1.4)$ & $47.7^{\mathrm{b}}(1.9)$ & $51.3^{\mathrm{b}}(2.1)$ & $56.1^{\mathrm{b}}(3.1)$ & $59.9^{\mathrm{b}}(72.5)$ & $45-50$ & $p<0.001$ \\
\hline Fat $(g)^{\S}$ & $33.2^{\mathrm{ac}}(3.2)$ & $34.6^{\mathrm{a}}(1.6)$ & $45.2^{\mathrm{b}}(2.2)$ & $44.5^{\text {bc }}(2.5)$ & $54.6^{\text {bd }}(3.7)$ & $61.6^{\mathrm{d}}(4.8)$ & $25-35$ & $p<0.001$ \\
\hline Fiber $(\mathrm{g})$ & $4.2^{\mathrm{a}}(0.5)$ & $4.8^{\mathrm{a}}(0.3)$ & $6.2^{\mathrm{b}}(0.3)$ & $6.37^{\mathrm{b}}(0.4)$ & $7.1^{\mathrm{b}}(0.6)$ & $5.6^{\mathrm{ab}}(0.7)$ & $25-31$ & $p<0.001$ \\
\hline Vitamin $B_{1}(m g)$ & $0.3^{\mathrm{ab}}(0.03)$ & $0.3^{\mathrm{a}}(0.02)$ & $0.4^{\mathrm{bc}}(0.02)$ & $0.4^{\mathrm{c}}(0.02)$ & $0.4^{\mathrm{c}}(0.03)$ & $0.5^{\mathrm{c}}(0.04)$ & $0.9-1.0$ & $p<0.001$ \\
\hline Vitamin $B_{2}(\mathrm{mg})$ & $0.5^{\mathrm{ab}}(0.06)$ & $0.5^{\mathrm{b}}(0.03)$ & $0.6^{\mathrm{ab}}(0.04)$ & $0.7^{\mathrm{ac}}(0.05)$ & $0.7^{\mathrm{ac}}(0.07)$ & $0.9^{\mathrm{bc}}(0.09)$ & $0.9-1.0$ & $p<0.001$ \\
\hline Vitamin $\mathrm{B}_{6}(\mathrm{mg})$ & $0.7^{\mathrm{ab}}(0.06)$ & $0.6^{b}(0.03)$ & $0.7^{\mathrm{ab}}(0.04)$ & $0.7^{\mathrm{a}}(0.05)$ & $0.9^{\mathrm{a}}(0.07)$ & $0.9^{\mathrm{ab}}(0.1)$ & $1-1.3$ & $p<0.001$ \\
\hline Vitamin C (mg) & $21.7(5.5)$ & $11.6(2.8)$ & $12.1(3.9)$ & $19.7(4.4)$ & $19.4(6.4)$ & $24.4(8.4)$ & $45-50$ & ns \\
\hline Calcium (mg) & $154.7^{\mathrm{a}}(59.4)$ & $204.6^{\mathrm{ab}}(30.4)$ & $238.4^{\mathrm{ab}}(41.3)$ & $266.5^{\mathrm{ab}}(47.2)$ & $267.7^{\mathrm{ab}}(68.7)$ & $489^{b}(90.3)$ & $600-1000$ & $p<0.001$ \\
\hline Iron (mg) & $3.7(3.4)$ & $4.3(1.7)$ & $5.2(2.4)$ & $6.1(2.7)$ & $6.8(3.9)$ & $7.8(5.1)$ & $10-13$ & ns \\
\hline Zinc (mg) & $4^{a}(0.4)$ & $4.1^{\mathrm{a}}(0.2)$ & $5.5^{\mathrm{b}}(0.3)$ & $5.8^{\mathrm{b}}(0.3)$ & $6.4^{\mathrm{b}}(0.4)$ & $7.1^{\mathrm{b}}(0.6)$ & $11.2-14$ & $p<0.001$ \\
\hline
\end{tabular}

'All values are presented as means (SE), mean values was adjusted with age, SES, and gender

\$ Recommended intake is based on Indonesian DRI (AKG 2004) and Dietary Reference Intakes 2005 by Institute of Medicine of The National Academies for carbohydrate and fiber

${ }^{\S}$ For fat, the Acceptable Macronutrient Distribution Ranges from Institute of Medicine is used.

${ }^{*} p<0.05$ is considered as statistically significant

\section{Discussions}

Girls, older children, and low SES sub-groups were more likely to skip their breakfast in comparison to their counterparts. These findings were consistent with other similar studies since it has been previously reported that girls are more likely to skip breakfast than boys. This may be due to the mislead perception of omitting breakfast for weight loss that was more common among girls (27). The prevalence of breakfast skipping also increases as children move to adolescence $(3,19,20)$. Moreover, breakfast skipping has been generally associated with the lower socioeconomic status (SES) due to the economic restriction $(19,22,22)$.

Furthermore, there is no statistically significant apparent in weight status differences shown by BMI $z$-score. This might be due to the nature of the study, 1 day cross sectional study using 24 hour dietary record, thus not enough to reveal the trends between breakfast behavior and weight status. Moreover, correlation between skipping breakfast and being overweight cannot be explained by the energy intake from self-reported diet (3). Another plausible reason was might be due to the different definition of breakfast skipping $(24,28$, 29). However, this will not diminish the importance of breakfast consumption and weight management, since many studies were also supported this relationship (2).

This study also showed that $15-30 \%$ DRI group in this population tended to be closer with the Indonesian DRI in terms of energy intake and micronutrient recommendation. Hence, the finding of the current study is also in support of the current healthy breakfast recommendation. However, lack of micronutrient and excess intake of fat (i.e. from fried foods as side dishes) and carbohydrates (i.e. white cooked rice (GI = 81 \pm 3 )) (42) during breakfast suggest an urgency to further improve breakfast quality e.g. richer in micronutrients and fiber, as well as lesser in fats and high glycemic index carbohydrates. Additionally, providing an educational program regarding healthy breakfast for Jakarta school aged children would also be beneficial.

\section{Healthy breakfast recommendation}

The result of this study has confirmed that breakfast consumption significantly contributes to whole diet nutrient adequacy as supported by current review (27). Nonetheless, current breakfast recommendation at about $15-30 \%$ of total energy of Indonesian DRI alone is insufficient. Several additional recommendations are essential.

- Encouragement to consume more whole fruits and fruit products such as fruit juice during breakfast. Whole fruit and $100 \%$ fruit juices are valuable sources of vitamins, minerals, and phytonutrients such as vitamin $\mathrm{C}$, folate, magnesium, potassium, and fibers. These products are the best choice to be incorporated within this population due to low consumption of vitamin $\mathrm{C}$ and fibers. Current review has also shown the beneficial effect of including whole fruit or 100 percent fruit juice in the likelihood of meeting daily nutrient recommendation (43) .

- Incorporation of fat free or low fat milk products to breakfast menu. Milk is considered as the most nutritious liquid due to its nutrient content such as calcium, potassium, magnesium, zinc, iron, riboflavin, vitamin A, folate, and vitamin D (44). Study has shown a significant inverse relationship between frequency of milk consumption and BMI in children, which may be 
beneficial for prevention of obesity (45). Indonesian people generally consumed considerably less amount of milk (only $11 \mathrm{~kg}$ per capita annually) compared to other ASEAN countries (46). In order to increase milk consumption during breakfast, integrated approach is needed, not only from parents, government, but also from food industry to create better marketing communication targeting children.

- Breakfast cereal consumption may also be considered as the substitute for rice and side dishes due to its numerous health benefits. It has been associated with lower saturated fatty acids (SFA) intake, higher dietary fiber and micronutrient intake compared with other types of breakfast or non-breakfast group $(3,47,48)$. It was also linked to a more favorable weight status (49) and better daily nutrient intakes $(13,47,48)$. Therefore, it is recommended to choose whole grain cereals, high-fiber, low-sugar, and micronutrients fortified RTE cereals as they provide additional nutrient and fiber intakes $(3,51$, 52)

For a more complete approach, Indonesian government has to encourage healthier breakfast campaign such as school breakfast program in Jakarta. Studies have shown that School Breakfast Program (SBP) has been linked to positive changes in meal content and nutrition outcomes $(53,54)$, mainly targeted for low SES groups where the highest prevalence of breakfast skipping was found in this study as well as other scientific review $(3,27)$. So far, there was a program initiated by Indonesian government namely PMTAS in 2010 (Penyediaan Makanan Tambahan Anak Sekolah - Providing Additional Food for School Aged Children). However, based on the recent report, this policy was inconsistent (38).

Last but not least, family breakfast is also recommended in increasing the likelihood of developing healthy breakfast habit for children in the future. Research had shown that frequencies of family meals boost the children likelihood to choose healthier food choices (55).

Future Recommendation

Further research examining biomarkers of nutritional status to nutrient daily intake is recommended. Longitudinal study investigating the relationship between breakfast consumption and weight status is also needed to obtain better impression related to this issue. Moreover, the inclusion of physical activity as the potential confounding factor would also be important to be investigated. Intervention studies investigating the effect of different types of breakfast (breakfast cereals, rice with side dishes, or streets versus homemade foods) is also essential to explore the possibility of breakfast cereals inclusion within this population. Additional research to further assess environmental determinants of breakfast behavior is also necessary.

\section{Conclusions}

Those who had breakfast significantly consumed more daily energy, carbohydrate, protein, fat, vitamin $\mathrm{B}_{2}$, calcium, and zinc but no significant differences were found in fiber intake and other micronutrients, although still considered higher intake. Breakfast contributed significantly to meet daily protein intake requirement. Nonetheless, this study found no significant difference on BMI $z$-score between two groups.

Skipping breakfast was more prevalent in girls, older children group, and low SES. About 39\% of school aged children living in Jakarta consumed breakfast less than 15\% Indonesian DRI, respectively. Furthermore, this study supported the current breakfast recommendation which was $15-30 \%$ of energy from Indonesian DRI with some additional encouragements.

\section{Acknowledgment}

The author is grateful to Health Development and Research Institute under Indonesian Ministry of Health for the 2010 RISKESDAS data provided. The author expresses gratitude to Prof. Stef Kremers and Prof. Fred Brouns for the guidance and valuable insights during the writing process. Special thank goes to Rob te Biesebeke, $\mathrm{PhD}$ for his insightful and whole-hearted guidance. The author would also thank Andre Binarto Wijaya for his sincere supports and great assistance in compiling the data used in this study. Highest appreciation also goes to Prof. Hardinsyah from Faculty of Human Ecology (FEMA) Bogor Agricultural University (IPB), Indonesia for the nutrition inputs The author thank Leonie Scheys, Aileen Mulja, and Natasha Ayuningtyas for the friendship. Last but not least, the author would also like to extend my deeply thank to Satriani Subagyo, Mardi Wu, PhD. and Susana, MSc., PD.Eng for their endless encouragement to make this study happened.

\section{References}

[1] Nicklas TA, Morales M, Linares A, Yang SJ, Baranowski T, De Moor C, et al. Children's meal patterns have changed over a 21-year period: the Bogalusa Heart Study. J Am Diet Assoc. [Comparative Study Research Support, Non-U.S. Gov't Research Support, U.S. Gov't, Non-P.H.S. Research Support, U.S. Gov't, P.H.S.]. 2004 May;104(5):753-61.

[2] Siega-Riz AM, Popkin BM, Carson T. Trends in breakfast consumption for children in the United States from 1965-1991. Am J Clin Nutr. [Research Support, Non-U.S. Gov't]. 1998 Apr;67(4):748S-56S.

[3] Rampersaud GC, Pereira MA, Girard BL, Adams J, Metzl JD. Breakfast habits, nutritional status, body weight, and academic performance in children and adolescents. J Am Diet Assoc. [Research Support, Non-U.S. Gov' Review]. 2005 May;105(5):743-60; quiz 61-2.

[4] Moy FM, Can CY, Siti Zaleha MK. Eating patterns of school children and adolescents in Kuala Lumpur. Malays J Nutr. 2006;12:1-10.

[5] So HK, Nelson EA, Li AM, Guldan GS, Yin J, Ng PC, et al. Breakfast frequency inversely associated with BMI and body fatness in Hong Kong Chinese children aged 9-18 years. Br J Nutr. [Research Support, Non-U.S. Gov't]. 2011 Sep;106(5):742-51. 
[6] Yang RJ, Wang EK, Hsieh YS, Chen MY. Irregular breakfast eating and health status among adolescents in Taiwan. BMC Public Health. [Research Support, Non-U.S. Gov't]. 2006;6:295.

[7] Evers S, Taylor J, Manske S, Midgett C. Eating and smoking behaviours of school children in southwestern Ontario and Charlottetown, PEI. Can J Public Health. [Research Support, Non-U.S. Gov't]. 2001 Nov-Dec;92(6):433-6.

[8] Shaw ME. Adolescent breakfast skipping: an Australian study. Adolescence. 1998 Winter;33(132):851-61.

[9] Barker M, Robinson S, Wilman C, Barker DJ. Behaviour, body composition and diet in adolescent girls. Appetite. [Research Support, Non-U.S. Gov't]. 2000 Oct;35(2):161-70.

[10] P.M. FSJ. Dietary habits and nutritional status of school aged children in Spain. Nutr Hosp. 2006;21:374-8.

[11] Kosti RI, Panagiotakos DB, Zampelas A, Mihas C, Alevizos A, Leonard $\mathrm{C}$, et al. The association between consumption of breakfast cereals and BMI in schoolchildren aged 12-17 years: the VYRONAS study. Public Health Nutr. [Research Support, Non-U.S. Gov't]. 2008 Oct;11(10):1015-21.

[12] Kovarova M, Vignerova J, Blaha P, Osancova K. Bodily characteristics and lifestyle of Czech children aged 7.00 to 10.99 years, incidence of childhood obesity. Cent Eur J Public Health. 2002 Dec;10(4):169-73.

[13] Sjoberg A, Hallberg L, Hoglund D, Hulthen L. Meal pattern, food choice, nutrient intake and lifestyle factors in The Goteborg Adolescence Study. Eur J Clin Nutr. [Comparative Study Research Support, Non-U.S. Gov't]. 2003 Dec;57(12):1569-78.

[14] Keski-Rahkonen A, Kaprio J, Rissanen A, Virkkunen M, Rose RJ. Breakfast skipping and health-compromising behaviors in adolescents and adults. Eur J Clin Nutr. [Research Support, Non-U.S. Gov't Twin Study]. 2003 Jul;57(7):842-53.

[15] Hardinsyah, Aries M. Jenis Pangan Sarapan dan Perannya Dalam Asupan Gizi Harian Anak Usia 6-12 Tahun di Indonesia. Jurnal Ilmu Gizi dan Pangan. 2012.

[16] Videon TM, Manning CK. Influences on adolescent eating patterns: the importance of family meals. J Adolesc Health. [Comparative Study]. 2003 May;32(5):365-73.

[17] Nicklas TA, Reger C, Myers L, O'Neil C. Breakfast consumption with and without vitamin-mineral supplement use favorably impacts daily nutrient intake of ninth-grade students. J Adolesc Health. [Research Support, Non-U.S. Gov't Research Support, U.S. Gov't, Non-P.H.S. Research Support, U.S. Gov't, P.H.S.]. 2000 Nov;27(5):314-21.

[18] Cheng TS, Tse LA, Yu IT, Griffiths S. Children's perceptions of parental attitude affecting breakfast skipping in primary sixth-grade students. J Sch Health. 2008 Apr;78(4):203-8.

[19] Delva J, O'Malley PM, Johnston LD. Racial/ethnic and socioeconomic status differences in overweight and health-related behaviors among American students: national trends 1986-2003. J Adolesc Health. [Comparative Study Research Support, N.I.H., Extramural Research Support, Non-U.S. Gov't]. 2006 Oct;39(4):536-45.

[20] Affenito SG, Thompson DR, Barton BA, Franko DL, Daniels SR, Obarzanek E, et al. Breakfast consumption by African-American and white adolescent girls correlates positively with calcium and fiber intake and negatively with body mass index. J Am Diet Assoc. [Comparative Study
Research Support, N.I.H., Extramural Research Support, U.S. Gov't, P.H.S.]. 2005 Jun;105(6):938-45.

[21] Utter J, Scragg R, Mhurchu CN, Schaaf D. At-home breakfast consumption among New Zealand children: associations with body mass index and related nutrition behaviors. J Am Diet Assoc. 2007 Apr;107(4):570-6.

[22] O'Dea JA, Caputi P. Association between socioeconomic status, weight, age and gender, and the body image and weight control practices of 6- to 19-year-old children and adolescents. Health Educ Res. [Comparative Study Research Support, Non-U.S. Gov't]. 2001 Oct;16(5):521-32.

[23] Sampson AE, Dixit S, Meyers AF, Houser R, Jr. The nutritional impact of breakfast consumption on the diets of inner-city African-American elementary school children. J Natl Med Assoc. 1995 Mar;87(3):195-202.

[24] Williams P. Breakfast and the diets of Australian children and adolescents: an analysis of data from the 1995 National Nutrition Survey. Int J Food Sci Nutr. [Comparative Study]. 2007 May;58(3):201-16.

[25] Pastore DR, Fisher M, Friedman SB. Abnormalities in weight status, eating attitudes, and eating behaviors among urban high school students: correlations with self-esteem and anxiety. J Adolesc Health. 1996 May;18(5):312-9.

[26] Nicklas TA, O'Neil C, Myers L. The importance of breakfast consumption to nutrition of children, adolescents, and young adults. Nutrition Today. 2004;39:30-9.

[27] Rampersaud GC. Benefits of Breakfast for Children and Adolescents: Update and Recommendations for Practitioners. American Journal of lifestyle medicine. 2008;2009(3 (2)):86-103.

[28] Abalkhail B, Shawky S. Prevalence of daily breakfast intake, iron deficiency anaemia and awareness of being anaemic among Saudi school students. Int J Food Sci Nutr. 2002 Nov;53(6):519-28.

[29] Mota J, Fidalgo F, Silva R, Ribeiro JC, Santos R. Relationship between physical activity, obesity, and meal frequency in adolescents. Ann Hum Biol. 2008;35:1-10.

[30] Timlin MT, Pereira MA, Story M, Neumark-Sztainer D. Breakfast eating and weight change in a 5-year prospective analysis of adolescents: Project EAT (Eating Among Teens). Pediatrics. 2008 Mar;121(3):e638-45.

[31] Berkey CS, Rockett HR, Gillman MW, Field AE, Colditz GA. Longitudinal study of skipping breakfast and weight change in adolescents. Int J Obes Relat Metab Disord. [Research Support, U.S. Gov't, Non-P.H.S. Research Support, U.S. Gov't, P.H.S.]. 2003 Oct;27(10):1258-66.

[32] Nurul Fadhilah A, Teo PS, Huybrechts I, Foo LH. Infrequent Breakfast Consumption Is Associated with Higher Body Adiposity and Abdominal Obesity in Malaysian School Aged Children. PLoS One. 2013;8(3):e59297.

[33] Timlin MT, Pereira MA. Breakfast frequency and quality in the etiology of adult obesity and chronic diseases. Nutr Rev. [Review]. 2007 Jun;65(6 Pt 1):268-81.

[34] Wyatt HR, Grunwald GK, Mosca CL, Klem ML, Wing RR, Hill JO. Long-term weight loss and breakfast in subjects in the National Weight Control Registry. Obes Res. [Research Support, Non-U.S. Gov't Research Support, U.S. Gov't, P.H.S.]. 2002 Feb;10(2):78-82. 
[35] Badan Pengembangan dan Penelitian Kesehatan. Riset Kesehatan Dasar (RISKESDAS). Jakarta. 2010.

[36] Murphy JM. Breakfast and learning: An updated review. Current Nutrition and Food Science. 2007;3(1):3-36.

[37] Raaijmakers LG, Bessems KM, Kremers SP, van Assema P. Breakfast consumption among children and adolescents in the Netherlands. Eur J Public Health. 2010 Jun;20(3):318-24.

[38] Hardinsyah, Aries M. Jenis Pangan Sarapan dan Perannya Dalam Asupan Gizi Harian Anak Usia 6-12 Tahun di Indonesia. Jurnal Ilmu Gizi dan Pangan. 2012.

[39] Agostoni C, Brighenti F. Dietary Choices for Breakfast in Children and Adolescents. Critical Reviews in Food Science and Nutrition. 2010;50(2):120-8.

[40] Taki Y, Hashizume H, Sassa Y, Takeuchi H, Asano M, Asano K, et al. Breakfast staple types affect brain gray matter volume and cognitive function in healthy children. PLoS One. [Research Support, Non-U.S. Gov't]. 2010;5(12):e15213.

[41] Soedibyo S, Gunawan H. Kebiasaan Sarapan di Kalangan Anak Usia Sekolah Dasar di Poliklinik Umum Departemen Ilmu Kesehatan Anak FKUI-RSCM. Sari Pediatri. 2009;11(1):66-70.

[42] ILSI. Dietary Fibre: Definition, Analysis, Physiology, and Health. ILSI Europe Consise Monograph Series. 2006.

[43] O'Neil CE, Nicklas TA. A review of the relationship between $100 \%$ fruit juice consumption and weight in children and adolescents. American Journal of lifestyle medicine. 2008;2:315-54.

[44] U.S Department of Human Health and Services. The Report of Dietary Guidelines Advisory Committee on Dietary Guidelines for Americans2005: Available from: http://www.health.gov/dietaryguidelines/dga2005/report.

[45] Barba G, Troiano E, Russo P, Venezia A, Siani A. Inverse association between body mass and frequency of milk consumption in children. Br J Nutr. [Research Support, Non-U.S. Gov't]. 2005 Jan;93(1):15-9.

[46] Slette J, Meylinah S. Indonesia Dairy and Products Annual Reports 2012: USDA Foreign Agricultural Services2012 Contract No.: ID1232.

[47] Deshmukh-Taskar PR, Nicklas TA, O'Neil CE, Keast DR, Radcliffe JD, Cho S. The relationship of breakfast skipping and type of breakfast consumption with nutrient intake and weight status in children and adolescents: the National Health and Nutrition Examination Survey 1999-2006. J Am Diet Assoc. [Research Support, Non-U.S. Gov't Research Support, U.S. Gov't, Non-P.H.S.]. 2010 Jun;110(6):869-78.

[48] Gibson SA, Gunn P. What's for breakfast? Nutritional implications of breakfast habits: insights from the NDNS dietary records. Nutrition Bulletin. 2011;36:78-86.

[49] Bazzano LA, Song Y, Bubes V, Good CK, Manson JE, Liu S. Dietary intake of whole and refined grain breakfast cereals and weight gain in men. Obes Res. [Research Support, N.I.H., Extramural Research Support, Non-U.S. Gov't]. 2005 Nov;13(11):1952-60.

[50] Barton BA, Eldridge AL, Thompson D, Affenito SG, Striegel-Moore RH, Franko DL, et al. The relationship of breakfast and cereal consumption to nutrient intake and body mass index: the National Heart, Lung, and Blood Institute Growth and Health Study. J Am Diet Assoc. [Research Support, N.I.H., Extramural Research Support, Non-U.S. Gov't Research Support, U.S. Gov't, P.H.S.]. 2005 Sep;105(9):1383-9.

[51] Cotton PA, Subar AF, Friday JE, Cook A. Dietary sources of nutrients among US adults, 1994 to 1996. J Am Diet Assoc. [Comparative Study]. 2004 Jun;104(6):921-30.

[52] Whittaker P, Tufaro PR, Rader JI. Iron and folate in fortified cereals. J Am Coll Nutr. 2001 Jun;20(3):247-54.

[53] Bhattacharya J, Currie J, Haider SJ. Breakfast of champion? The School breakfast program and the nutrition of children and families. Journal of Human Resources. 2006;41:445-66.

[54] Clark MA, Fox MK. Nutritional quality of the diets of US public school children and the role of the school meal programs. J Am Diet Assoc. [Research Support, Non-U.S. Gov't Research Support, U.S. Gov't, Non-P.H.S.]. 2009 Feb;109(2 Suppl):S44-56.

[55] Haapalahti M, Mykkanen H, Tikkanen S, Kokkonen J. Meal patterns and food use in 10- to 11-year-old Finnish children. Public Health Nutr. [Research Support, Non-U.S. Gov't]. 2003 Jun;6(4):365-70.

[56] Cho S, Dietrich M, Brown CJ, Clark CA, Block G. The effect of breakfast type on total daily energy intake and body mass index: results from the Third National Health and Nutrition Examination Survey (NHANES III). J Am Coll Nutr. [Research Support, Non-U.S. Gov't]. 2003 Aug;22(4):296-302. 